\title{
Effects of Temperature and Salinity on Larval Development of Pagurus bernhardus (Decapoda, Paguridae)*
}

\author{
R. R. Dawirs \\ Biologische Anstalt Helgoland, D-2192 Helgoland, Federal Republic of Germany
}

\begin{abstract}
The hermit crab Pagurus bernhardus L. was reared from egg to first crab stage at $6{ }^{\circ} \mathrm{C}, 12^{\circ} \mathrm{C}$ and $18{ }^{\circ} \mathrm{C}$. At $6{ }^{\circ} \mathrm{C}$, development was completed after 107 to $112 \mathrm{~d}_{i}$ at $12{ }^{\circ} \mathrm{C}$, after 49 to $54 \mathrm{~d}_{i}$ at $18{ }^{\circ} \mathrm{C}$, after 33 to $35 \mathrm{~d}$ following hatching. Survival rates were $6.7 \%$ both at $6^{\circ}$ and $18{ }^{\circ} \mathrm{C}$; they were $20 \%$ at $12{ }^{\circ} \mathrm{C}$. A simple graphical model was constructed which predicts occurrence, presence and settling of $P$. bernhardus larvae in the field. According to this model, in Helgoland waters (North Sea), duration of larval development lasts about 35 to $62 \mathrm{~d}$, depending on the water temperature during and after hatching. Shortest development (about $35 \mathrm{~d}$ ) is postulated for larvae hatching at the beginning of August. Complete rearing to metamorphosis was accomplished in $20 \%$ and $30 \% \mathrm{~S}\left(18{ }^{\circ} \mathrm{C}\right)$. In $10 \% \mathrm{~S}$, Zoea 1 larvae exhibit $100 \%$ mortality 2 to $5 \mathrm{~d}$ after hatching. No differences in development duration, mortality, etc. were noticed at $20 \%$ and $30 \% \mathrm{~S}$. The observation that a salinity of $20 \%$ does not cause recognizable stress is discussed in relation to local larval distribution.
\end{abstract}

\section{INTRODUCTION}

The present study was carried out as part of a joint project of the Biologische Anstalt Helgoland and aims at producing model conceptions of the pelagic ecosystem in the German Bight (Biologische Anstalt Helgoland, 1978; Kinne, 1977; Anger and Nair, 1979). Problems involved in the cultivation of decapod crustaceans have been reviewed by Provenzano (1976), Rice and Williamson (1970), Roberts (1975), and Kinne (1977).

The zoea larvae and the megalopa of Pagurus bernhardus were first described by Rathke (1840). Sars (1890) described Zoea 1 and Zoea 2, as well as the megalopa. Further descriptions can be found in Williamson (1915), Webb (1921), Jackson (1913), and Pike and Williamson (1958). A detailed description combined with remarks on size data of particular instars was given by Mac Donald et al. (1957).

Like Hyas araneus (Anger and Nair, 1979) Pagurus bernhardus is a very common component of the pelagic

\footnotetext{
- Contribution to research project Experimentelle Marine Okosystemanalyse' sponsored by 'Bundesministerium für Forschung und Technologie', Bonn (Grant No. MFU-0328/1).
}

ecosystem of the German Bight. P. bernhardus not only is abundant near Helgoland; it is almost worldwide distributed (Jackson, 1913; Bookhout, 1964). Considering the fact that a female $P$. bernhardus carries about 12000 to 15000 eggs during each spawning season, this benthic decapod also constitutes an important factor in the pelagic environment (Jackson, 1913; Bookhout, 1964).

According to Jackson (1913), zoeae of Pagurus bernhardus are present in boreal seas and in the Mediterranean Sea from April to the end of September, followed by the megalopa. Lebour (1947) reports on larvae of Pagurus sp. from inshore plankton off Plymouth (England) throughout the year, except December. In Helgoland waters, $P$. bernhardus larvae were caught from January to December (Greve and Reiners, personal communication). The reliability of statements related to local distributions is limited. Taxonomic determinations of larvae are often difficult and many descriptions are based only on plankton catches. Moreover, in most areas more than one species of a given genus is present (e. g. in Helgoland waters also Eupagurus pubescens). To date, only Bookhout (1964) has succeeded in rearing larvae of $P$. bernhardus. Therefore, little is known about their biology, ecology and physiology. 


\section{MATERLAL AND METHODS}

\section{Obtaining and Handling of Larvae}

Egg carrying fernales of Pagurus bernhardus were dredged from 'Helgoländer Tiefe Rinne', a deep (ca. $30-50 \mathrm{~m}$ ) channel southwest of Helgoland, in July 1978. The females were kept at $6{ }^{\circ} \mathrm{C}$. At this temperature hatching was never observed. Since temperature treatment delays hatching, it becomes possible to obtain larvae for experimentation over an extended period of time (over ca. 2 months). Such 'retardation' was successfully practiced also with Hyas araneus (Anger and Nair, 1979).

In order to obtain Pagurus bernhardus larvae, egg carrying females were kept separately in a flowthrough system at temperatures between $15^{\circ} \mathrm{C}$ and $17^{\circ} \mathrm{C}$. Larvae always appeared within one week.

The larvae were reared in $600 \mathrm{ml}$ beakers, filled with $500 \mathrm{ml}$ of natural sea water from Helgoland $(29-30 \% \mathrm{~S})$. This water had been filtered through a stratified filter (pore size: ca $1 \mu \mathrm{m}$ ). The initial larval density was $\mathrm{n}=15$ larvae $\left(\hat{=} 30 \mathrm{l}^{-1}\right)$. Slight aeration provided oxygen saturation and turbulence which prevented the settling of food organisms. Taking into account results of feeding experiments with Brachionus plicatilis and Artemia salina nauplii (Dawirs, 1979), only freshly hatched nauplii of $A$. salina were used as food for all larval stages (ca 10 nauplii $\mathrm{Inl}^{-1}$; source: Kew, Melbourne, Australia; World Ocean Ltd., 87 Packington St.).

\section{Experiments}

All experiments were carried out in temperature controlled rooms. Three temperatures $\left(6^{\circ}, 12^{\circ}, 18^{\circ} \mathrm{C}\right)$ and three salinities $(10,20,30 \% \mathrm{~S})$ were compared as to their influence on the larval development. The different salinities were obtained by dilution of natural sea water with water from an ion exchanger. Salinity experiments were carried out at $18^{\circ} \mathrm{C}$. After hatching, the larvae were immediately exposed to experimental salinities, i. e. without prior adaptation. All experiments were conducted in triplicate. For examination and water change the contents of rearing beakers were carefully sifted through $35 \mu \mathrm{m}$ gauze. This mesh-size is small in relation to larval size (Mac Donald et al., 1957), and facilitates safe transfer (by wash bottle) into a convenient dish for observation and sorting. After checking the larvae under the dissecting microscope, all dead individuals, exuviae and food organisms were removed. Only living larvae were retumed to the beakers with new water before feeding. All larvae used in experiments on salinity and temperature influences had been produced by a single female Pagurus bernhardus. In order to simulate seasonal effects, each constant temperature was combined with a defined day-night regime: $6{ }^{\circ} \mathrm{C}$, LD $8: 16 ; 12^{\circ} \mathrm{C}$, LD $12: 12$; $18^{\circ} \mathrm{C}, \operatorname{LD} 16: 8$.

\section{RESULTS}

\section{Influence of Salinity on Larval Development}

Figure 1 illustrates larval survival rates and duration of molting periods as a function of salinity. In $10 \% \mathrm{~S}$ all larvae died 2 to $5 \mathrm{~d}$ after hatching; in $20 \%$ and $30 \% \mathrm{~S}$, development to the first crab stage was completed. In $20 \% \mathrm{~S}$ metamorphosis of all survivors took place between 30 and $33 \mathrm{~d}$ after hatching, while in $30 \% \mathrm{~S}$ first crab stages appeared between 33 and $35 \mathrm{~d}$ after hatching (Fig. 4).

There is no significant difference in the influence of these two salinities on survival rate, molting periods and occurrence of particular larval stages (Figs 2, 3 and

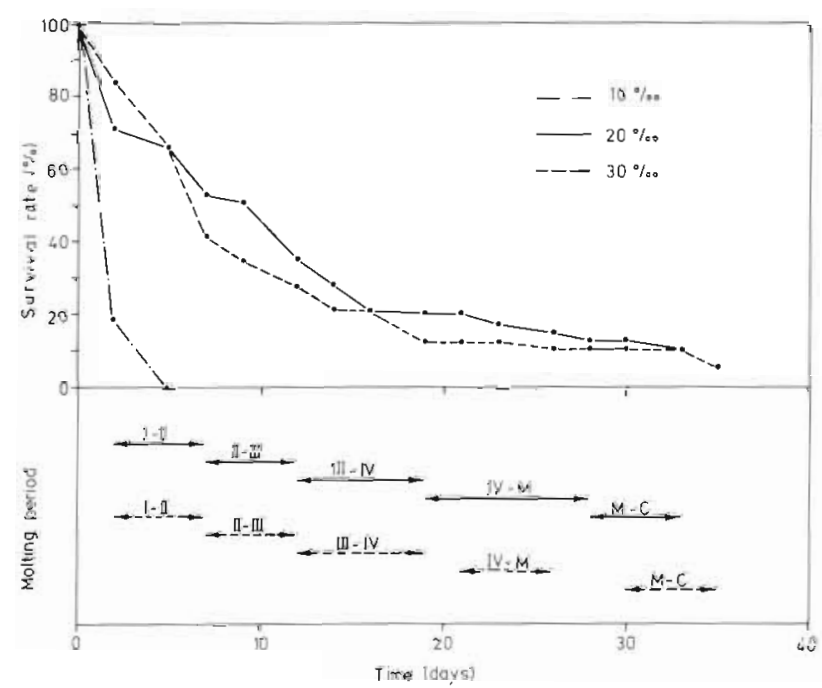

Fig. 1. Pagurus bernhardus. Cumulative survival rates and molting periods of larvae in relation to salinity. I, II, III, IV: zoeal stages; $M$ : megalopa stage; $C$ : first crab stage

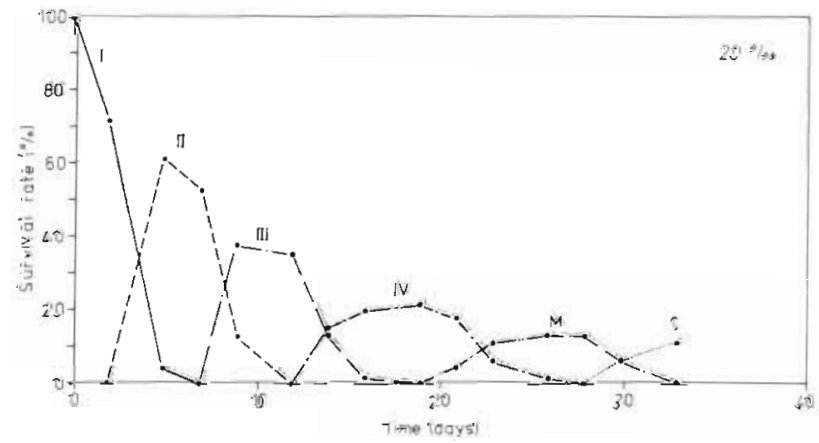

Fig. 2. Pagurus bernhardus. Survival rate in $20 \%$ S. I, II, III IV: zoeal stages; $M$ : megalopa stage; $C$ : first crab stage 


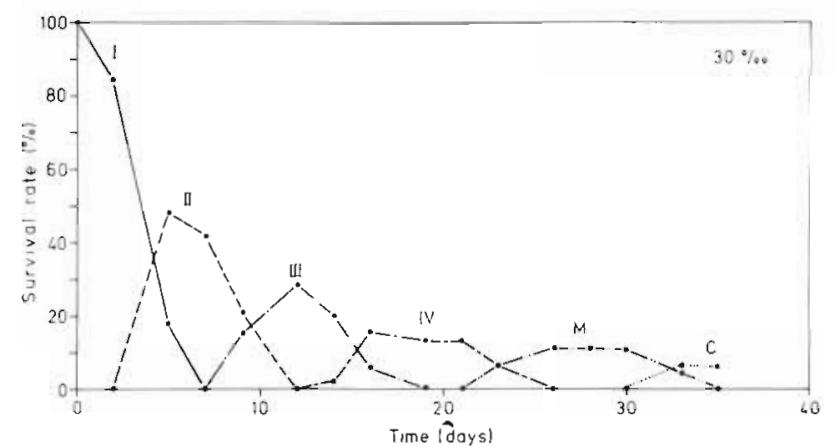

Fig. 3. Pagurus bemhardus. Suvival rate in $30 \% \mathrm{~S}$. I, II, III, $\Gamma$ : zoeal stages; $\mathrm{M}$ : megalopa stage; $\mathrm{C}$ : first crab stage

4). In $20 \% \mathrm{~S}, 11.3 \%$ ( $\hat{=} 5$ individuals) of the larvae completed their development; in $30 \% \mathrm{~S} .6 .7 \%(\bumpeq)$ individuals). Development from Zoea 1 to megalopa was very similar in both cases. In $10 \% \mathrm{~S}$, no molting was observed, mortality of Zoea 1 was always $100 \%$ (Figs 4 and 5). The total duration of larval development is shown in Figure 5.

\section{Influence of Temperature on Larval Development}

Three temperatures were tested: $6^{\circ}, 12^{\circ}$ and $18^{\circ} \mathrm{C}$. The test series at $18^{\circ} \mathrm{C}$ is identical with one of the salinity experiments ( $\hat{=} 30 \%$ S).

At all three constant temperatures, Pagurus bernhardus was reared to the first crab stage. Differences were found in duration of development and mortality rate (Fig. 6). Mortality rate (per unit time) increased from $6^{\circ}$ to $18{ }^{\circ} \mathrm{C}$. Survival after $30 \mathrm{~d}$ from hatching, for example, was $46.7 \%$ at $6{ }^{\circ} \mathrm{C}, 26.7 \%$ at $12{ }^{\circ} \mathrm{C}$, and $11.3 \%$ at $18{ }^{\circ} \mathrm{C}$. Simultaneously the duration of development was shortened by increasing temperature. At $6{ }^{\circ} \mathrm{C}$, the first crab stages occurred at the earliest, after $107 \mathrm{~d}_{i}$ at $12^{\circ} \mathrm{C}$, after $49 \mathrm{~d}$. At $18^{\circ} \mathrm{C}$, first metamorphosis was completed after 33 d. Developmental duration of particular stages and of total larval life is shown in Figure 10. Total mortality remains in the same order of magnitude at each temperature (Fig. 9).

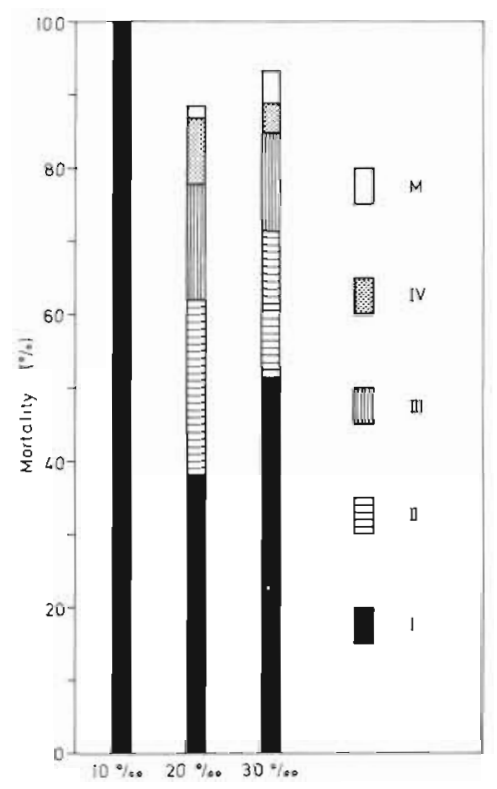

Fig. 4. Pagurus bernhardus. Cumulative mortality in relation to salinity. $I_{1} \Pi_{t}$ III, IV: zoeal stages; $M$ : megalopa stage

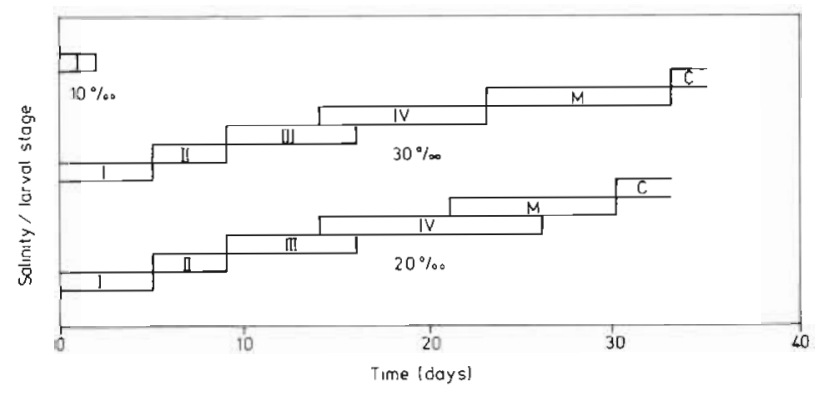

Fig. 5. Pagurus bernhardus. Duration of larval development in relation to salinity. I, II, III, IV: zoeal stages: M: megalopa stage; $C$ : first crab stage

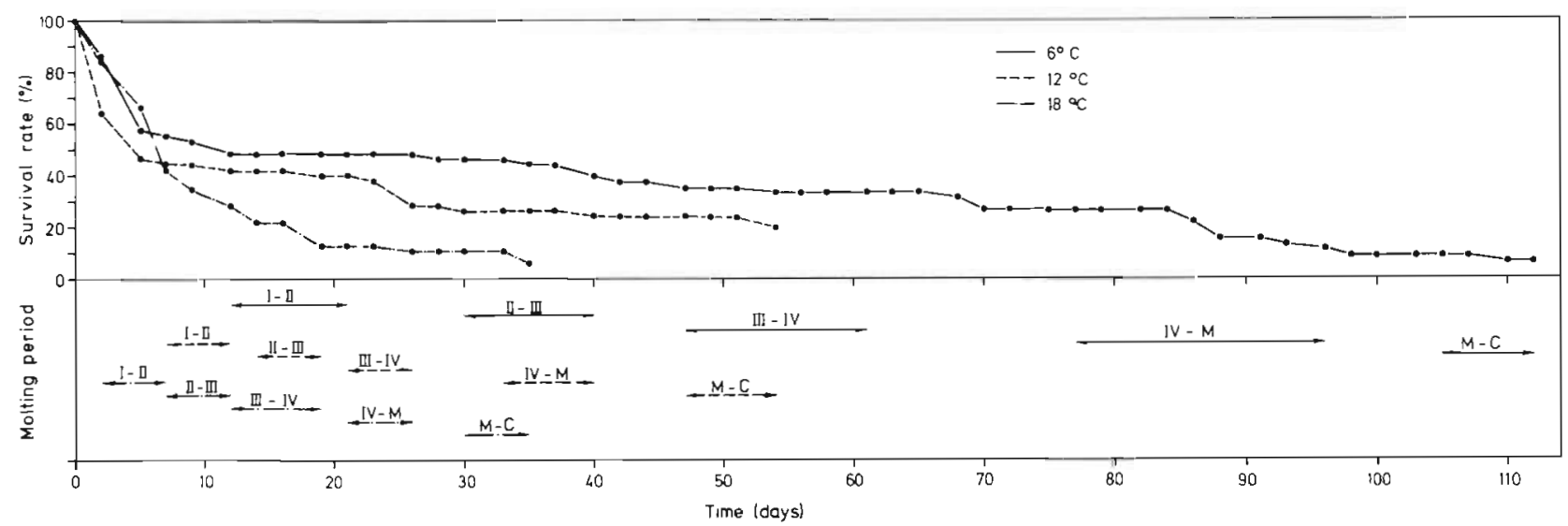

Fig. 6. Pagurus bernhardus. Cumulative survival rates and molting periods in relation to temperature. I, II, III, IV: zoeal stages; M: megalopa stage; C:first crab stage 


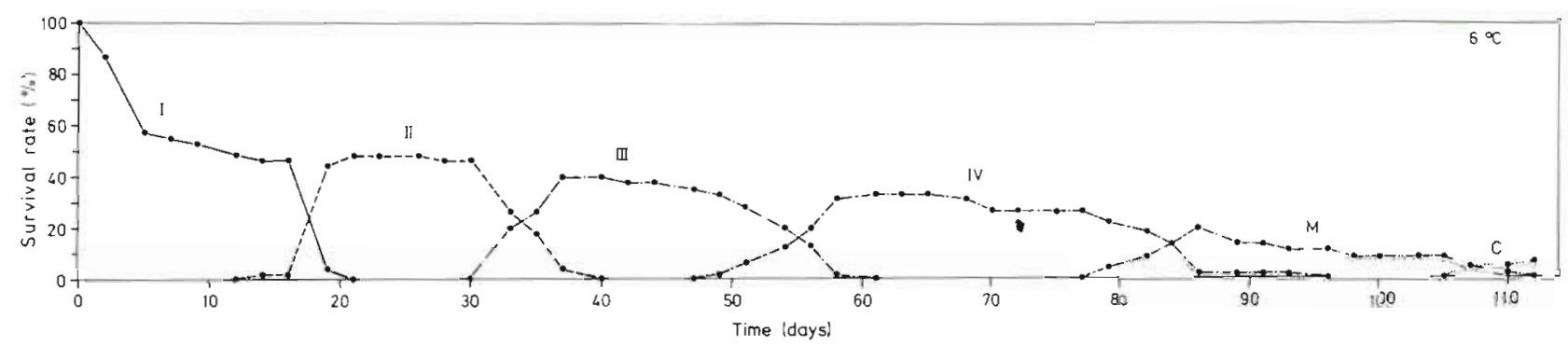

Fig. 7. Pagurus bernhardus. Survival rate at $6^{\circ} \mathrm{C}$. I, II, III, IV: zoeal stages; M: megalopa stage; C: first crab stage

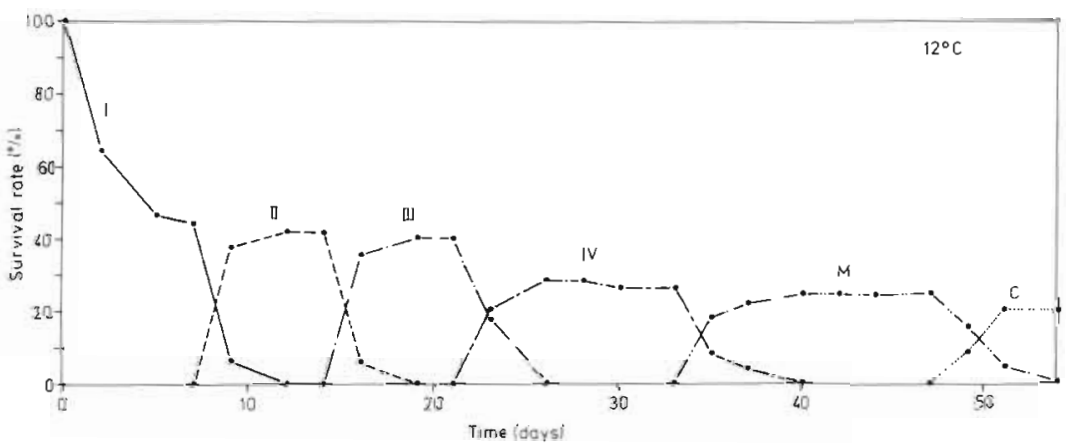

Fig. 8. Pagurus bernhardus. Survival rate at $12{ }^{\circ} \mathrm{C}$. I, II, III, IV: zoeal stages; M: megalopa stage; C: first crab stage

'Optimal' rearing temperature seems to be about $12{ }^{\circ} \mathrm{C}$ (mortality: $80 \%$, versus $93.3 \%$ at both $6^{\circ}$ and $18^{\circ} \mathrm{C}$ ). Molting periods at $6^{\circ} \mathrm{C}$ are markedly prolonged as compared to $12^{\circ}$ and $18^{\circ} \mathrm{C}$ (Fig. 6). The development does not indicate irregularities (Figs 3, 7 and 8).

Mean durations of larval stages can be obtained from Figures 3,4 and 8. From these average values idealized curves have been derived revealing the relationships between temperature and development duration in all larval stages (Fig. 11). In contrast to Hyas araneus, where no significant temperature influence could be detected above $10^{\circ} \mathrm{C}$ (Anger and Nair, 1979), Iarvae of Pagurus bernhardus are presumably affected even above $18^{\circ} \mathrm{C}$.

In nature no constant temperature conditions exist. Figure 12 shows the seasonal variation of temperature for Helgoland waters (long term means, after Weigel, 1978). These data, together with the relationships shown in Figure 11, have been used to calculate approximate rates of larval development in the field (Fig. 12).

This simple graphical model shows the duration of total larval development (left scale) and the duration of particular instars depending on time of hatching (abscissa) and temperature during this period (right scale). The model applies to larvae hatching between mid-June and mid-August. When the last larvae considered in this model complete their development (about the second half of December) water temperature is about $6^{\circ} \mathrm{C}$. That corresponds approximately to the lowest experimental temperature applied in this study.

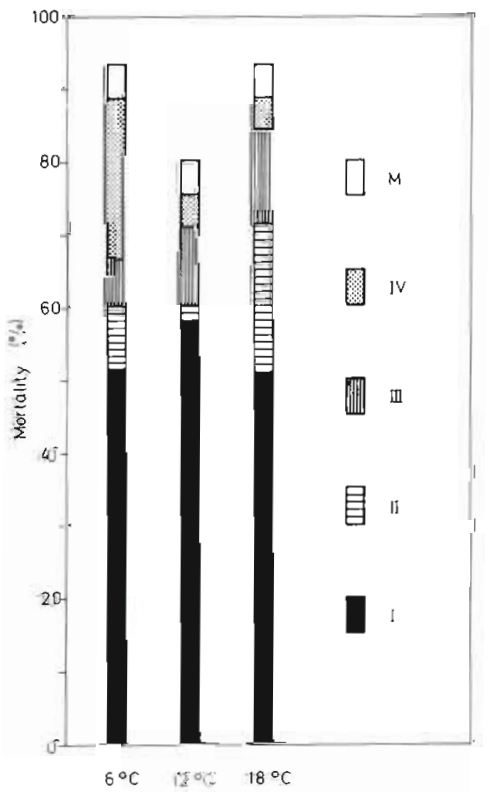

Fig. 9. Pagurus bernhardus. Cumulative mortality in relation to temperature. I, II, III, IV: zoeal stages; M: megalopa stage

The model provides an assessment of the planktonic phase of Pagurus bernhardus in Helgoland waters. The individual range of this period is about 33 to $62 \mathrm{~d}$. Due to the temperature maximum in August (Fig. 12), development duration is shortened from about $41 \mathrm{~d}$ (for larvae hatching in mid-June) to about $35 \mathrm{~d}$ (for larvae hatching in the beginning of August). Thus, larvae hatching at this time presumably have the shortest 


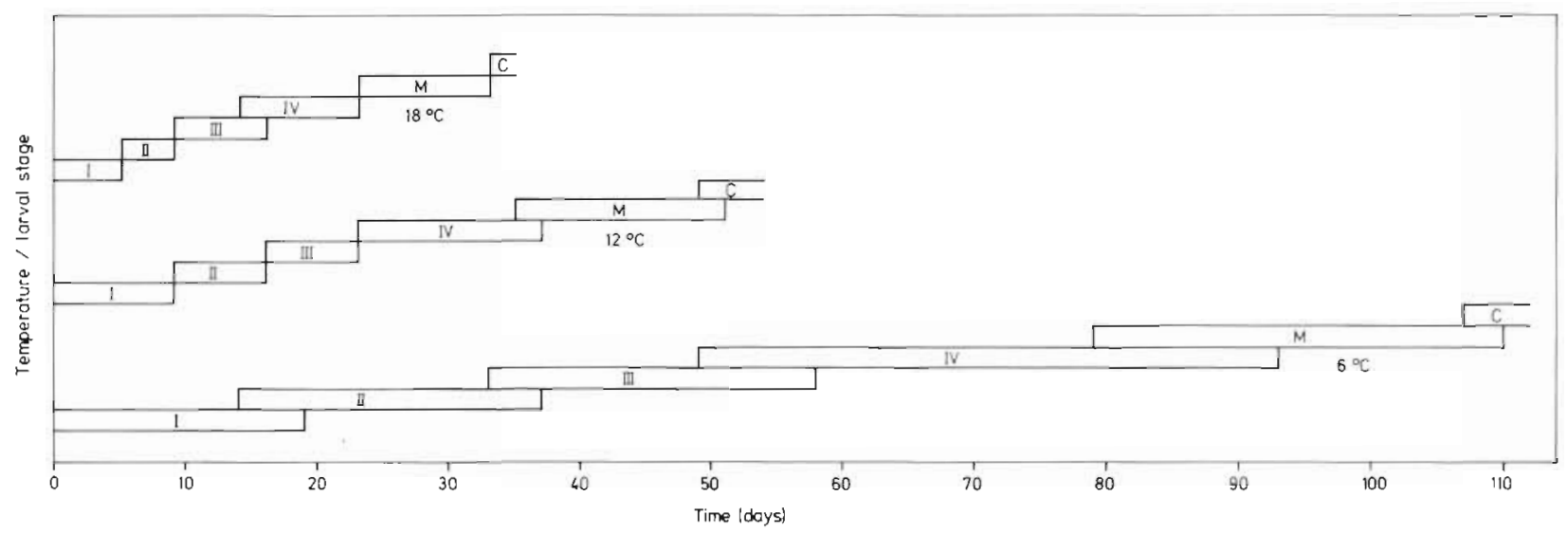

Fig. 10. Pagurus bernhardus. Duration of larval development in relation to temperature. I, II, III, IV: zoeal stages; M: megalopa stage; C: first crab stage

pelagic phase during the year. For all larvae entering the pelagial later, development duration is prolonged again. Hence larvae hatching in mid-October, i. e. at the end of the assumed hatching period, reach metamorphosis after about $62 \mathrm{~d}$ (in late December). In the period of maximum hatching activity (mid-June to mid-August; Fig. 12) larval development lasts about 35 to $41 \mathrm{~d}$.

Further, the model shows that all five instars will coexist in the plankton from mid-July to the end of October. Starting in mid-June (the assumed beginning of the hatching period) the successive larval stages appear in relative short intervals of about one week.

\section{DISCUSSION}

The only data for Pagurus bernhardus corresponding to the present paper were given by Bookhout (1964). He worked at a constant temperature of $10^{\circ} \mathrm{C}$. In two experimental series $(20 \% \mathrm{~S})$ Bookhout recorded $100 \%$ mortality in the Zoea 3 stage, although he had adapted the larvae step by step to the lower salinity. Also, in $25 \% \mathrm{~S}$ metamorphosis was not reached in his two test series. All larvae died as Zoea 4 or as megalopa. First crab stages only occurred at $30 \%$ and $35 \% \mathrm{~S}$. The only distinct methodological difference between Bookhout's and my experiments seems to be rearing temperature: Bookhout employed a constant temperature of $10^{\circ} \mathrm{C}$, while my rearing success was obtained at $18^{\circ} \mathrm{C}$.

The fact that there is obviously no difference in rearing success in $20 \%$ and $30 \%$ S corresponds to the regional distribution of the larvae of Pagurus bernhardus. The population around Helgoland is exposed to the influence of brackish water with salinities down to $25 \% \mathrm{~S}$ originating from the Elbe estuary. Hence, larvae will surely be drifted to regions with less than

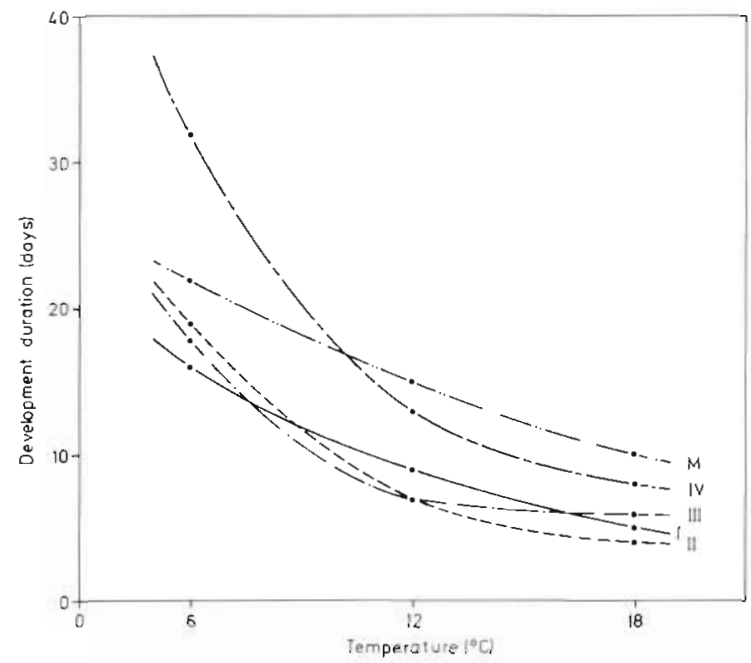

Fig. 11. Pagurus bernhardus. Relation between developmental time and temperature. Mean values from Figures 3, 7 and 8. I, II, III, IV: zoeal stages; $M$ : megalopa stage

$20 \% \mathrm{~S}$. Larvae of $P$. bernhardus also enter the Baltic Sea through the Kattegat; they can be found in the deeper parts of the Kiel Bight, where salinities are about $20 \%$ to $25 \% \mathrm{~S}$. Taking into account the results of my salinity experiments it can be stated that larvae of $P$. bernhardus not only tolerate salinities down to $20 \% \mathrm{~S}$ but are able to metamorphose under these conditions.

There is also some information on the salinity tolerance of other pagurid species. In salinities between $22.5 \%$ and $35 \% \mathrm{~S}$ Pagurus samuelis could be reared to Zoea 4 , in $29 \% \mathrm{~S}$ only to the megalopa (Coffin, 1958). P. longicarpus can complete its development in a much wider salinity range, with an optimum between $18 \%$ and $13.5 \% \mathrm{~S}$ (Roberts, 1971a). Detailed discussions regarding the influence of salinity on larval development in various decapod crustaceans can 


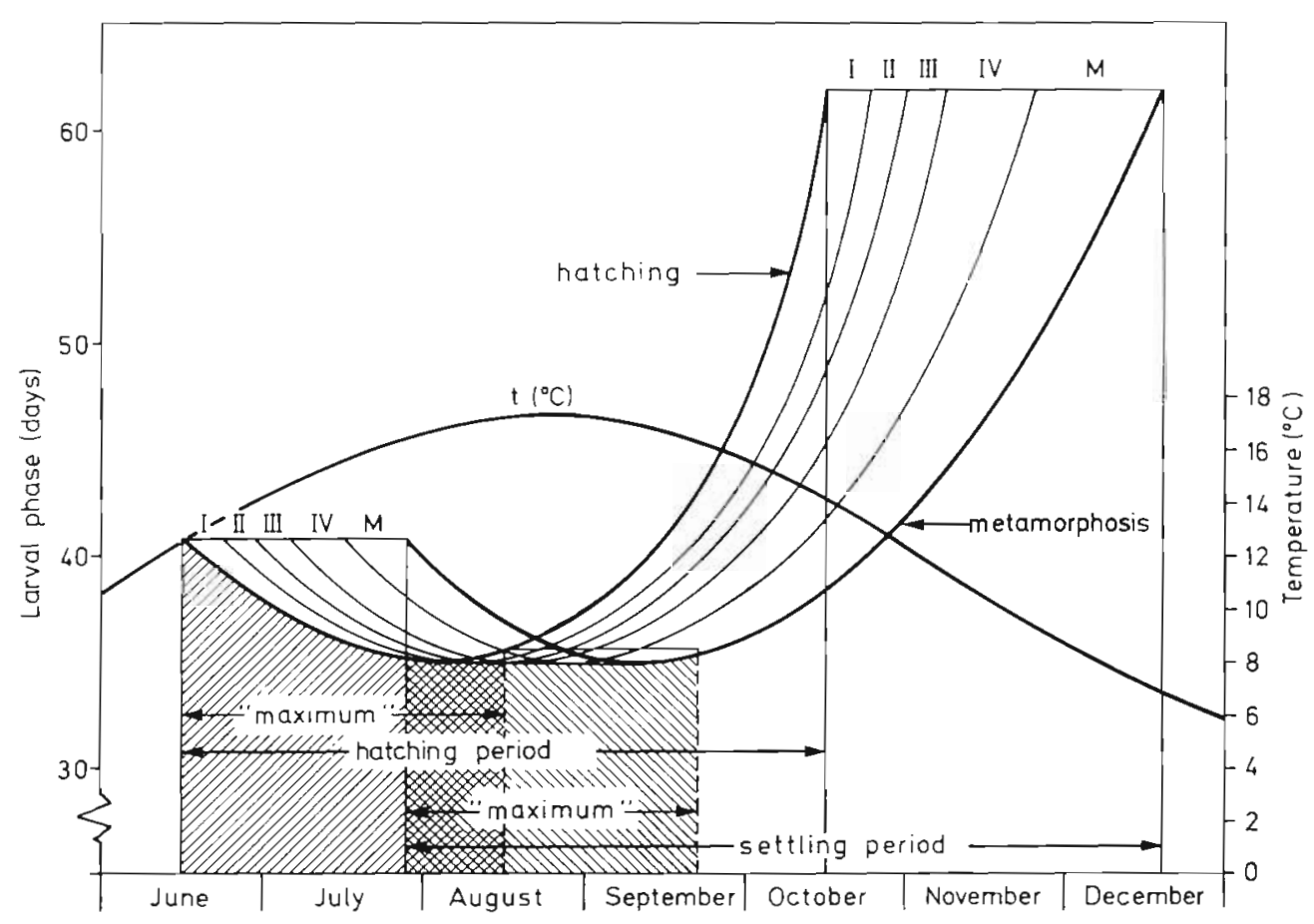

Fig. 12. Pagurus bernhardus. Graphical model predicting relations between temperature and larval development in the field. I, II, II, $\Gamma$ : zoeal stages; $M$ : megalopa stage

be found, for example, in Roberts (1971a) and Costlow and Bookhout (1964).

Comparison of the effects of different rearing temperatures can provide basic data, such as rates of mortality and duration of development in single larval stages and length of total larval development. By means of these data it is possible to estimate the periods during which Pagurus bernhardus is present in the pelagic environment. The graphical model presented in Figure 12 shows the basic significance of the thermal climate, especially during hatching. In Hyas araneus (Anger and Nair, 1979) the principal hatching period lasts from mid-February to mid-March, at the lowest seasonal water temperature (less than $4{ }^{\circ} \mathrm{C}$ ). This leads to an exclusive occurrence of Zoeae 1 in February and March. Beginning in mid-April the frequency of Zoeae 2 increases until mid-May while Zoeae 1 disappear gradually at the same time. Later, megalopae occur in the plankton. Most megalopae metamorphose till mid-June, the latest till mid-July.

Such distinct separation cannot be assumed for Pagurus bernhardus (Fig. 12). In this species occurs an overlap of nearly 3 months between the first metamorphosis and the last hatching within the total assumed hatching period of 4 months. Hence, the total period of metamorphosis in nature is extended to about 5 months, beginning at the end of July and ending at the end of December. The assumed maximum hatching period (mid-June to mid-August) corresponds to a maximum settling period of about 2 months (end of July to end of September).

In Hyas araneus (Anger and Nair, 1979) there is at no time any overlap of hatching and metamorphosis in the field, because the period of hatching is shorter than the maximum developmental time. The hatching season of maximally 3 months (mid-February to mid-May) is followed by a settling period of somewhat more than 1 month (beginning of June to mid-July). In $H$. araneus the maximum hatching period (mid-February to midMarch) corresponds to a very short settling period (beginning to mid-June). This intense 'invasion' of the benthic environment by $H$. araneus is opposed to a gradual settling by Pagurus bernhardus.

Since my model only considers the temperature factor it cannot be exactly applied to field conditions, but it can serve as a useful approximation as long as nutrition is grossly comparable in the field and in the laboratory.

Acknowledgements: I am very grateful to all those members of the Biologische Anstalt Helgoland (BAH) who supported this work. In particular, I am thankful to Dr. K. Anger for stimulating discussions. Dr. W. Greve and F. Schorn supplied Brachionus plicatilis; DI. E. Wahl and M. Janke, Artemia salina. D. Packmor drew the figures. Dr. J. Markham corrected the manuscript. Professor O. Kinne provided working facilities at the Marine Station of the BAH, and Professor W. Noodt supervised my work. 


\section{LITERATURE CITED}

Anger, K. and Nair, K. K. C. (1979). Laboratory experiments on the larval development of Hyas araneus (Decapoda, Majidae). Helgoländer wiss. Meeresunters., 32, 36-54.

Biologische Anstalt Hegoland (1978). Jahresbericht 1977, pp 60,79 .

Bookhout, C. G. (1964). Salinity effects on larval development of Pagurus bernhardus (L.) reared in the laboratory. Ophelia, 1, 275-294.

Coffin, H. G. (1958). The laboratory culture of Pagurus samuelis (Stimpson) (Crustacea, Decapoda). Walla Walla College Publ., 22, 1-5.

Costlow, J. D., Jr. and Bookhout, C. G. (1964). An approach to the ecology of marine invertebrate larvae. Proc. Symp. Exp. Mar. Ecol, 2, 69-75.

Dawirs, R. R. (1979). Aufzuchtbedingungen ökosystemrelevanter Dekapoden der Nordsee (Pagurus benhardus und Carcinus maenas). Dipl., Universität Kiel.

Jackson, H. G. (1913). Eupagurus. Mem. Liverpool Mar. Biol. Comm., 21, 1-79.

Kinne, O. (1977a). International Helgoland Symposium 'Ecosystem research': Opening address. Helgoländer wiss. Meeresunters., 30, 1-7.

Kinne, O. (1977b). Research cultivation. In O. Kinne (Ed.), Marine Ecology, Vol. III, Cultivation, Part 2. Wiley, Chichester. pp. 579-1293.

Lebour, M. V. (1947). Notes on the inshore plankton of Plymouth. J. mar. biol. Ass. U. K., 26. 527-547

Mac Donald, J. D., Pike, R. B. and Williamson, D. I. (1957) Larvae of the British species of Diogenes, Pagurus, Anapa- gurus and Lithodes (Crustacea, Decapoda). Proc. Zool. Soc. Lond., 128, 209-257.

Pike, R. B. and Williamson, D. I. (1958). Crustacea Decapoda: Larvae. Fick. Ident. Zooplancton, 81.

Provenzano, A. J., Jr. (1967). Recent advances in the laboratory culture of decapod larvae. Biol. Ass. India, Symp. Ser., 2.

Rathke, H. (1840). Zur Entwicklungsgeschichte der Dekapoden. Arch. Naturgesch., 6, 241-249.

Rice, A. L. and Williamson, D. I. (1970). Methods of rearing larval decapod crustacea. Helgoländer wiss. Meeresunters., $20,417-434$

Roberts, M. H., Jr. (1971). Larval development of Pagurus longicarpus Say reared in the laboratory. II. Effects of reduced salinity on larval development. Biol. Bull., mar. biol. Lab., Woods Wole, 140, 104-116.

Roberts, M. H., Jr. (1975). Culture techniques for decapod crustacean larvae. In W. L. Smith and M. H. Chanley (Eds), Culture of Marine Invertebrate animals. Plenum Press, New York. pp. 209-220.

Sars, G. O. (1890). Bidrag til kundskaben on Decapodernes Forvandinger. Arch. Math. Naturv., 13.

Webb, G. E. (1921). The larvae of the Decapoda Macura and Anomura of Plymouth. J. mar. biol. Ass. U. K., 12, 385-425.

Weigel, H.-P. (1978). Temperature and salinity observations from Helgoländer Reede in 1967. Annls biol., Copenh., 33, $1-35$.

Williamson, H. C. (1915). Crustacea, Decapoda, Larven. In Nordisches Plankton, Vol. III, 6 (zool.). Verlag von Lipsius \& Tischer, Kiel, Leipzig. pp. 315-588.

This paper was presented by Professor H.-P. Bulnheim; it was accepted for printing on November 2, 1979. 